\title{
Analyst
}

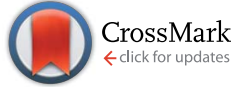

Cite this: Analyst, 2014, 139, 6028

Received 25th July 2014

Accepted 11th September 2014

DOI: $10.1039 / c 4 a n 01366 b$

www.rsc.org/analyst

\section{Chemiluminescence detection with water-soluble iridium(III) complexes containing a sulfonate- functionalised ancillary ligand $\uparrow$}

\author{
Josephine Truong, ${ }^{a}$ Kara B. Spilstead, ${ }^{a}$ Gregory J. Barbante, ${ }^{a}$ Egan H. Doeven, ${ }^{a}$ \\ David J. D. Wilson, ${ }^{\mathrm{b}}$ Neil W. Barnett, ${ }^{a}$ Luke C. Henderson, ${ }^{\text {ac }}$ Jarrad M. Altimari, ${ }^{a}$
} Samantha C. Hockey, ${ }^{a}$ Ming Zhou ${ }^{d}$ and Paul S. Francis ${ }^{* a}$

The chemiluminescence from four cyclometalated iridium(III) complexes containing an ancillary bathophenanthroline-disulfonate ligand exhibited a wide range of emission colours (green to red), and in some cases intensities that are far greater than the commonly employed benchmark reagent, $\left[\mathrm{Ru}(\mathrm{bpy})_{3}\right]^{2+}$. A similar complex incorporating a sulfonated triazolylpyridine-based ligand enabled the emission to be shifted into the blue region of the spectrum, but the responses with this complex were relatively poor. DFT calculations of electronic structure and emission spectra support the experimental findings.

\section{Introduction}

Cyclometalated iridium(III) complexes have been widely explored as electrochemiluminescence (ECL) reagents ${ }^{1-9}$ because of their wide range of emission colours and high luminescence efficiencies, which offer greater sensitivity than the benchmark tris $\left(2,2^{\prime}\right.$-bipyridine)ruthenium(II) $\left(\left[\mathrm{Ru}(\mathrm{bpy})_{3}\right]^{2+}\right)$ reagent, and the ability to create multi-coloured ECL systems. ${ }^{10-14}$ Preliminary studies suggest that cyclometalated iridium(III) complexes could also provide superior chemiluminescence detection of various analytes, ${ }^{15-21}$ but the limited solubility of many commercially available iridium(III) complexes in aqueous solution has restricted their application.

We have previously demonstrated the use of the highly polar bathophenanthroline-disulfonate (BPS) as an ancillary ligand in a cyclometalated iridium(III) complex to increase its solubility in aqueous solution. ${ }^{15}$ Moreover, we showed that bis(2-phenylpyridine- $\left.C^{2}, N\right)$ (bathophenanthroline-disulfonate)iridium(III) $\left(\left[\operatorname{Ir}(\mathrm{ppy})_{2}(\mathrm{BPS})\right]^{-}\right.$, Fig. 1a: 1) provided greater sensitivity (in terms of the calibration gradient) than $\left[\mathrm{Ru}(\mathrm{bpy})_{3}\right]^{2+}$ for the

${ }^{a}$ Centre for Chemistry and Biotechnology, School of Life and Environmental Sciences, Faculty of Science, Engineering and Built Environment, Deakin University, 75 Pigdons Road, Waurn Ponds, Victoria 3216, Australia.E-mail: paul.francis@deakin.edu.au

${ }^{b}$ Department of Chemistry, La Trobe Institute for Molecular Sciences, La Trobe University, Victoria 3086, Australia

'Institute for Frontier Materials, Deakin University, 75 Pigdons Road, Waurn Ponds, Victoria 3216, Australia

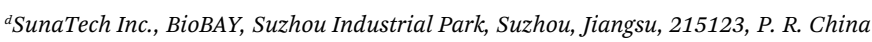
$\dagger$ Electronic supplementary information (ESI) available: Additional ground state singlet HOMO and LUMO and excited state triplet spin density surfaces; HOMO, LUMO and singlet-triplet transition energies; and Cartesian coordinates of optimized geometries. See DOI: 10.1039/c4an01366b (a)

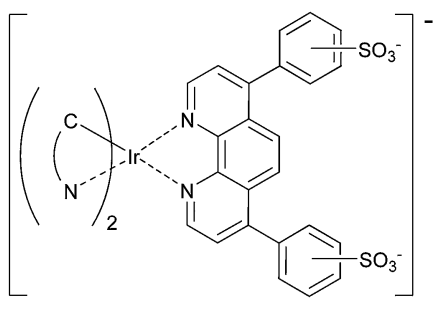

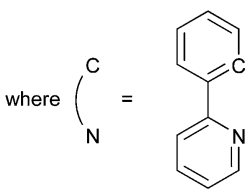

(1)<smiles>Fc1ccc(-c2ccccn2)c(F)c1</smiles>

(2)<smiles>c1ccc(-c2nc3ccccc3s2)cc1</smiles>

(3)<smiles>c1ccc(-c2nccc3ccccc23)cc1</smiles>

(4) (b)

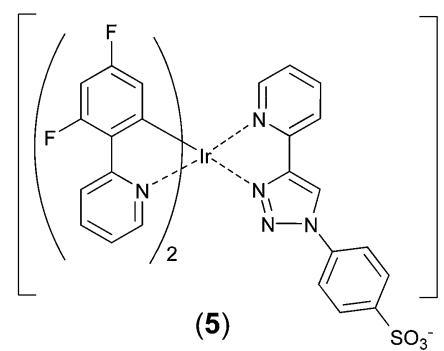

Fig. 1 Iridium(III) complexes containing sulfonate-functionalised ligands. (a) Complexes containing the BPS ligand. The position of the sulfonate groups on BPS varies depending on the source of the ligand. $22,25-27$ In this study, the $p-m^{\prime}$-regioisomer ${ }^{23}$ was used. (b) A complex containing the 1-phenylsulfonate-1,2,3-triazol-4-ylpyridine (STP) ligand. 
determination of oxalate, but the ruthenium-based reagent still provided better limits of detection due to its lower blank responses. ${ }^{15}$ Investigations with the difluoro-phenylpyridine analogue, $\left[\operatorname{Ir}(\mathrm{df}-\mathrm{ppy})_{2}(\mathrm{BPS})\right]^{-}$(2), revealed significant differences in the selectivity of light producing reactions of 1 and $2 .{ }^{17}$ Moreover, complex 2 provided a superior limit of detection for the pharmaceutical furosemide than that obtained using $\left[\mathrm{Ru}(\mathrm{bpy})_{3}\right]^{2+}$. Following the publication of this work, ${ }^{\mathbf{1 5}, 17}$ these and other bis-cyclometalated iridium complexes containing an ancillary BPS ligand (Fig. 1a; 1-4) have been utilised for a variety of luminescence-based applications $5^{5,12,22-24}$ and they are now commercially available.

Herein we explore, for the first time, the chemiluminescence of recently commercialised complexes $\left[\operatorname{Ir}(\mathrm{bt})_{2}(\mathrm{BPS})\right]^{-}(3)$ and $\left[\operatorname{Ir}(\mathrm{piq})_{2}(\mathrm{BPS})\right]^{-}(\mathbf{4})$, in addition to a novel complex containing a sulfonated triazolylpyridine ancillary ligand (Fig. 1b; 5), in direct comparison with the previously studied $\left[\operatorname{Ir}(\mathrm{df}-\mathrm{ppy})_{2}(\mathrm{BPS})\right]^{-}$(2) and $\left[\mathrm{Ru}(\mathrm{bpy})_{3}\right]^{2+}$ reagents.,.$^{3,17}$

\section{Results and discussion}

We initially examined the chemiluminescence of complexes 2-4 and $\left[\mathrm{Ru}(\mathrm{bpy})_{3}\right]^{2+}$ dissolved in $50: 50$ acetonitrile-water, upon reaction with cerium(Iv) sulfate and three different analytes ofloxacin, furosemide and codeine - using flow injection analysis, under the conditions described in our previous investigation. ${ }^{17}$ As shown in Table 1, these complexes exhibit a wide range of oxidation potentials and maximum emission wavelengths. The difference in overall emission colour (and reaction rates) could be clearly seen by visual examination of each chemiluminescence reaction with cerium(Iv) and ofloxacin when the reactants were continuously merged in a dual-inlet serpentine $^{28}$ flow-cell (Fig. 2).

For quantitative comparison, the reagents $\left(1 \times 10^{-5} \mathrm{M}\right)$ were injected into the analyte solution $\left(1 \times 10^{-6} \mathrm{M}\right)$, which merged with the oxidant $\left(1 \times 10^{-3} \mathrm{M}\right.$ in $\left.0.05 \mathrm{M} \mathrm{H}_{2} \mathrm{SO}_{4}\right)$ in a T-piece just prior to entering a transparent PTFE coil flow-cell mounted in front of a photomultiplier tube. As observed in our previous work under these conditions, ${ }^{\mathbf{1 7}}$ the green-light emitting $[\operatorname{Ir}(\mathrm{df}-$ ppy $\left.)_{2}(\mathrm{BPS})\right]^{-}$complex gave the greatest chemiluminescence signals (and signal-to-blank $(S / B)$ ratios) with furosemide (Table 2). However, the current work revealed that

Table 1 Selected spectroscopic and electrochemical data

\begin{tabular}{|c|c|c|c|}
\hline & \multicolumn{2}{|c|}{ Photoluminescence } & \multirow{2}{*}{$\begin{array}{l}\text { Oxidation } \\
E_{\text {ox }}(\mathrm{V} v s . \mathrm{Ag} / \mathrm{AgCl})^{b}\end{array}$} \\
\hline & $\lambda_{\mathrm{em}}{ }^{a}(\mathrm{~nm})$ & $\phi_{\mathrm{PL}}^{23}$ & \\
\hline$\left[\operatorname{Ir}(\mathrm{df}-\mathrm{ppy})_{2}(\mathrm{BPS})\right]^{-}$ & 549 & 0.29 & 1.54 \\
\hline$\left[\operatorname{Ir}(\mathrm{bt})_{2}(\mathrm{BPS})\right]^{-}$ & 573 & 0.40 & 1.36 \\
\hline$\left[\mathrm{Ru}(\mathrm{bpy})_{3}\right]^{2+}$ & 624 & 0.06 & 1.23 \\
\hline$\left[\operatorname{Ir}(\mathrm{piq})_{2}(\mathrm{BPS})\right]^{-}$ & 632,595 & 0.10 & 1.19 \\
\hline
\end{tabular}

${ }^{a} 10 \mu \mathrm{M}$ in $50: 50$ acetonitrile-water at room temperature. Spectra were corrected for the wavelength dependence of the detector response and monochromator transmission. ${ }^{29}{ }^{b} 0.1 \mathrm{mM}$ in acetonitrile-water containing $0.1 \mathrm{M} \mathrm{TBAPF}_{6}$ at room temperature, measured using a potentiostat with three-electrode configuration.

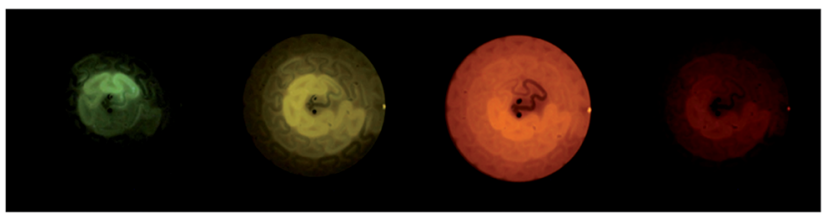

Fig. 2 Chemiluminescence of (from left to right): $\left[\operatorname{lr}(\mathrm{df}-\mathrm{ppy})_{2}(\mathrm{BPS})\right]^{-}$, $\left[\operatorname{lr}(\mathrm{bt})_{2}(\mathrm{BPS})\right]^{-},\left[\mathrm{Ru}(\mathrm{bpy})_{3}\right]^{2+}$ and $\left[\operatorname{Ir}(\mathrm{piq})_{2}(\mathrm{BPS})\right]^{-}\left(5 \times 10^{-4} \mathrm{M}\right)$, with cerium(IV) $\left(1 \times 10^{-3} \mathrm{M}\right)$ and ofloxacin $\left(1 \times 10^{-3} \mathrm{M}\right)$, in a dual-inlet serpentine flow-cell.

$\left[\operatorname{Ir}(\mathrm{bt})_{2}(\mathrm{BPS})\right]^{-}$provided greater chemiluminescence signals (and $S / B$ ratios) with ofloxacin and codeine, in addition to the second greatest values with furosemide. This is considerably different to the reported order of 'oxidative-reduction' ECL intensities $\left(\left[\mathrm{Ru}(\text { bipy })_{3}\right]^{2+}(1)>\left[\operatorname{Ir}(\text { piq })_{2}(\mathrm{BPS})\right]^{-}(0.079)>\right.$ $\left.\left[\operatorname{Ir}(\mathrm{bt})_{2}(\mathrm{BPS})\right]^{-}(0.016)>\left[\operatorname{Ir}(\mathrm{df}-\mathrm{ppy})_{2}(\mathrm{BPS})\right]^{-}(0.001)\right)$ at relatively low metal-complex concentration with tri- $n$-propylamine coreactant in buffered aqueous solution, despite the similarities in their light-producing reaction pathways. ${ }^{30,31}$ The complex exhibiting the highest photoluminescence quantum yield $\left(\left[\operatorname{Ir}(\mathrm{bt})_{2}(\mathrm{BPS})\right]^{-}\right.$, see Table 1) generally gave the largest chemiluminescence intensities, but overall, the correlation between photoluminescence quantum yields and chemiluminescence intensity was poor.

Ofloxacin calibrations prepared under these conditions exhibited a 7-fold steeper gradient, 2-fold higher intercept, and an order of magnitude superior limit of detection $(3 \sigma)$ of $3 \times$ $10^{-9} \mathrm{M}$ ofloxacin using $\left[\operatorname{Ir}(\mathrm{bt})_{2}(\mathrm{BPS})\right]^{-}$, compared to that obtained using $\left[\mathrm{Ru}(\mathrm{bpy})_{3}\right]^{2+}$.

When we increased the chemiluminescence reagent concentrations by orders of magnitude (to $1 \mathrm{mM}$, for example), the advantage of the iridium(III) complexes was diminished or even overcome. We have observed similar effects in the case of the $\left[\operatorname{Ir}(\mathrm{df}-\mathrm{ppy})_{2}(\mathrm{BPS})\right]^{-}$complex ${ }^{17}$ and also for some related ruthenium(II) complexes, ${ }^{26}$ such as $\left[\mathrm{Ru}(\mathrm{BPS})_{3}\right]^{4-}$. There is evidence to suggest that this (at least in part) arises from differences in the kinetics of the competing light-producing reactions of the oxidised reagent with the analyte and with the solvent. ${ }^{17}$ This effect explains the apparent discrepancy between the data in Table 2 and the relative intensities of light seen emanating from the flow-cells in Fig. 2, as the photographs were obtained using much higher concentrations of the reactants.

Table 2 Chemiluminescence signal $(\mathrm{mV})$ and signal/blank ratio shown in parenthesis, for $10 \mu \mathrm{M}$ reagent (in 50:50 acetonitrile-water) injected ${ }^{a}$ into $1 \mu \mathrm{M}$ analyte, and then merged with $1 \mathrm{mM}$ cerium(Iv) in $0.05 \mathrm{M} \mathrm{H}_{2} \mathrm{SO}_{4}$

\begin{tabular}{llll}
\hline & Ofloxacin & Furosemide & Codeine \\
\hline$\left[\operatorname{Ir}(\text { df-ppy })_{2}(\mathrm{BPS})\right]^{-}$ & $3.7(28)$ & $3.3(25)$ & $0.13(1.0)$ \\
{$\left[\operatorname{Ir}(\mathrm{bt})_{2}(\mathrm{BPS})\right]^{-}$} & $29(51)$ & $3.1(4.6)$ & $2.4(2.7)$ \\
{$\left[\mathrm{Ru}(\mathrm{bpy})_{3}\right]^{2+}$} & $4.6(15)$ & $0.7(2.5)$ & $0.45(1.6)$ \\
{$\left[\operatorname{Ir}(\text { piq })_{2}(\mathrm{BPS})\right]^{-}$} & $6.6(12)$ & $1.1(1.2)$ & $0.97(1.6)$
\end{tabular}

${ }^{a} n=3$; the relative standard deviation (RSD) of replicate injections was generally below $2.5 \%$. 
The presence of the BPS ligands in complexes 1-4 elicits a considerable bathochromic shift in the emission (compared to their homoleptic tris-cyclometalated analogues), towards a less sensitive region of the photodetector. To the naked eye, $\left[\operatorname{Ir}(\mathrm{ppy})_{3}\right]$ emits green light $\left(\lambda_{\max }=530 \mathrm{~nm}\right),{ }^{9}$ whereas the luminescence of $\left[\operatorname{Ir}(\mathrm{ppy})_{2}(\mathrm{BPS})\right]^{-}$is orange $\left(\lambda_{\max }=628 \mathrm{~nm}\right) .{ }^{17}$ Similarly, the light from $\left[\operatorname{Ir}(\mathrm{df}-\mathrm{ppy})_{3}\right]$ is blue $\left(\lambda_{\max }=492 \mathrm{~nm}\right),{ }^{9}$ but that from $\left[\operatorname{Ir}(\mathrm{df}-\mathrm{ppy})_{2}(\mathrm{BPS})\right]^{-}$is shifted into the green $\left(\lambda_{\max }\right.$ $=547$ nm; ${ }^{17}$ Fig. 2). To avoid this effect while maintaining reasonable solubility in water, we sought to prepare a sulfonated derivative of 1-phenyl-1,2,3-triazol-4-ylpyridine to use as an alternative ancillary ligand to BPS. In recent investigations of electrochemiluminescence detection with iridium(III) complexes, ${ }^{6,9}$ triazolylpyridine ligands have been shown to exert hypsochromic effects by stabilising the HOMO energy (compared to their homoleptic cyclometalated counterparts). In initial attempts to synthesise the sulfonated ligand and then form the iridium(III) complex, purification of the product from precursors was problematic. However, the target was readily obtained by first preparing the analogous thiol ligand (7) via an efficient two step synthetic sequence (Fig. 3a), then forming the iridium(III) complex (9; Fig. 3b), before oxidising the thiol with potassium peroxymonosulfate to form the desired sulfonate (5). The reagent was then directly prepared, without further isolation of the product, by appropriate dilution with an aqueous sulfuric acid solution.

(a)

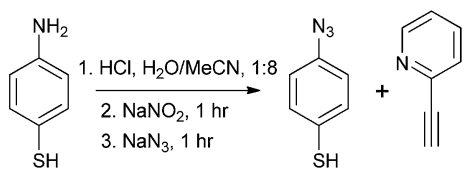

(b)

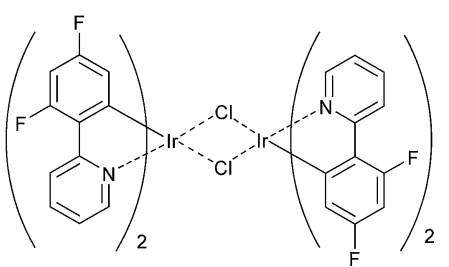

(8)

7, dichloromethane reflux under $\mathrm{N}_{2}, 24 \mathrm{hr}$

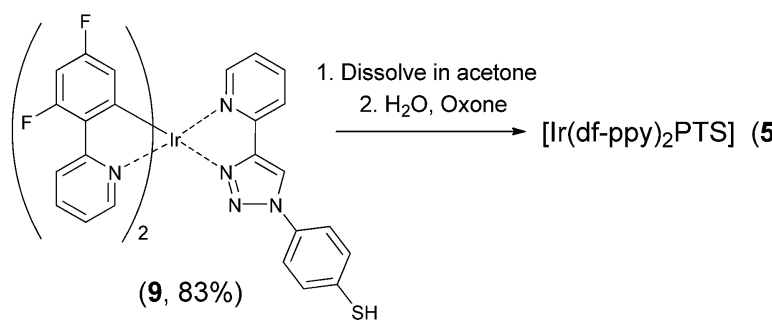

Fig. 3 Synthesis of (a) the thiol ligand, and (b) the iridium(III) complex with an ancillary sulfonate-functionalised ligand.
As expected, the emission maxima of $\left[\operatorname{Ir}(\mathrm{df}-\mathrm{ppy})_{2}(\mathrm{STP})\right]$ $\left(\lambda_{\max }=453\right.$ and $482 \mathrm{~nm}$; Fig. 4a) occurred at much shorter wavelengths than those of $\left[\operatorname{Ir}(\mathrm{df}-\mathrm{ppy})_{2}(\mathrm{BPS})\right]^{-}\left(\lambda_{\max }=498\right.$ and $526 \mathrm{~nm}$; Fig. 4b). For both complexes, the presence of vibronic fine structure is indicative of ligand-centred (LC) character. ${ }^{32}$

Comparison of the novel complex against $\left[\operatorname{Ir}(\mathrm{df}-\mathrm{ppy})_{2}(\mathrm{BPS})\right]^{-}$, $\left[\operatorname{Ir}(\mathrm{bt})_{2}(\mathrm{BPS})\right]^{-}$, and $\left[\mathrm{Ru}(\mathrm{bpy})_{3}\right]^{2+}$ in aqueous solution (without acetonitrile) was conducted using flow injection analysis, after optimisation of conditions (manifold configuration, flow rate, cerium(Iv) concentration). The presence of only one sulfonate group on the ancillary ligand (and the fluorine groups on the phenylpyridine ligands) of [Ir(df-ppy $\left.)_{2}(\mathrm{STP})\right]$ lowered its solubility in aqueous solution compared to the other complexes. We therefore limited the reagent concentration in these comparisons to $1 \times 10^{-5} \mathrm{M}$. Greater signals and $S / B$ ratios were obtained by injecting the reagent into a cerium(Iv) stream which then merged with the analyte in the detector (which in this case was a GloCel $^{\mathrm{TM}}$ with dual-inlet serpentine flow cell). ${ }^{28}$

As shown in Table 3, $\left[\operatorname{Ir}(\mathrm{df}-\mathrm{ppy})_{2}\right.$ (STP)] generally gave the lowest chemiluminescence intensities, but its $S / B$ ratios for furosemide were superior to those of other iridium complexes. Nevertheless, the emission from $\left[\operatorname{Ir}(\mathrm{df}-\mathrm{ppy})_{2}(\mathrm{STP})\right]$ is the shortest wavelength chemically-induced luminescence from a metal complex in aqueous solution reported to date. Similar to the above findings in mixed solvents, $\left[\operatorname{Ir}(\mathrm{bt})_{2}(\mathrm{BPS})\right]^{-}$and $\left[\operatorname{Ir}(\mathrm{df}-\mathrm{ppy})_{2}(\mathrm{BPS})\right]^{-}$exhibited much higher chemiluminescence intensities than $\left[\mathrm{Ru}(\mathrm{bpy})_{3}\right]^{2+}$ (Table 3). Furthermore, the considerable differences in their intensities were observed over a wide range of analyte concentrations (e.g. Fig. 5). Under these conditions, however, the conventional ruthenium(II) chelate gave superior $S / B$ ratios, due to its much lower blank responses. Consequently, the limit of detection $(3 \sigma)$ of ofloxacin using $\left[\mathrm{Ru}(\mathrm{bpy})_{3}\right]^{2+}\left(3 \times 10^{-9} \mathrm{M}\right)$ was better than that using $\left[\operatorname{Ir}(\mathrm{bt})_{2}(\mathrm{BPS})\right]^{-}\left(6 \times 10^{-9} \mathrm{M}\right)$.

The differences in the blank signals of the reagents arise from: (i) the rate that each metal complex is oxidised by cerium(Iv) (i.e. the proportion of the metal complex that is in its oxidised form within the detection zone); (ii) the relative rates of the chemiluminescent (blank) reaction of the oxidised metal-

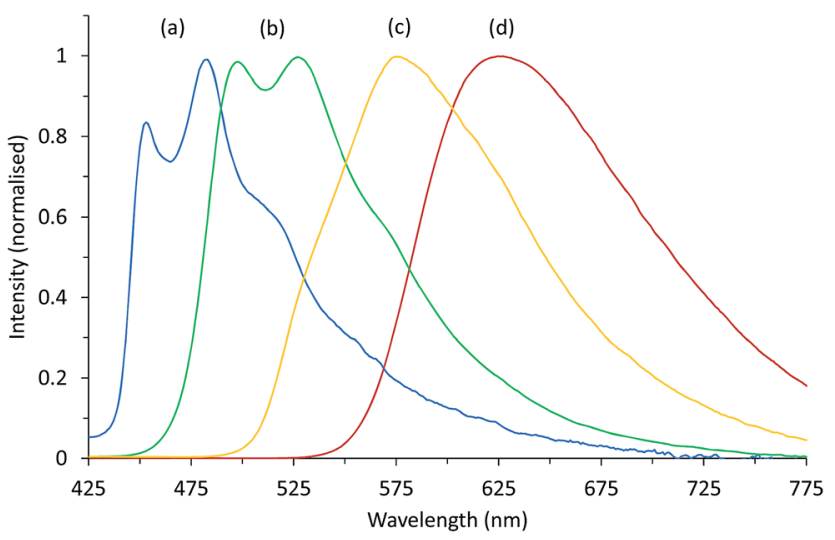

Fig. 4 Photoluminescence emission spectrum of (a) [lr(df-ppy $\left.)_{2}(\mathrm{STP})\right]$, (b) $\left[\operatorname{lr}(\mathrm{df}-\mathrm{ppy})_{2}(\mathrm{BPS})\right]^{-}$, (c) $\left[\operatorname{lr}(\mathrm{bt})_{2}(\mathrm{BPS})\right]^{-}$, and (d) $\left[\mathrm{Ru}(\mathrm{bpy})_{3}\right]^{2+}$, at $10 \mu \mathrm{M}$ in $0.05 \mathrm{M} \mathrm{H}_{2} \mathrm{SO}_{4}$. 
Table 3 Chemiluminescence signal $(\mathrm{mV})$ and signal/blank ratio shown in parenthesis, for $10 \mu \mathrm{M}$ reagent (in $0.05 \mathrm{M} \mathrm{H}_{2} \mathrm{SO}_{4}$ ) injected ${ }^{a}$ into $1 \mathrm{mM}$ cerium(Iv) in $0.05 \mathrm{M} \mathrm{H}_{2} \mathrm{SO}_{4}$, and then merged with $1 \mu \mathrm{M}$ analyte

\begin{tabular}{llll}
\hline & Ofloxacin & Furosemide & Codeine \\
\hline$\left[\operatorname{Ir}(\mathrm{df}-\mathrm{d} \text {-py })_{2}(\mathrm{STP})\right]^{-}$ & $0.6(1.3)$ & $3.2(6)$ & $0.2(0.5)$ \\
{$\left[\operatorname{Ir}(\mathrm{df}-\mathrm{ppy})_{2}(\mathrm{BPS})\right]^{-}$} & $91.4(16)$ & $8.4(1.4)$ & $17.9(3)$ \\
{$\left[\operatorname{Ir}(\mathrm{bt})_{2}(\mathrm{BPS})\right]^{-}$} & $536(31)$ & $79.9(4)$ & $16.6(1.1)$ \\
{$\left[\mathrm{Ru}(\mathrm{bpy})_{3}\right]^{++}$} & $24.9(196)$ & $2.6(20)$ & $0.8(8)$
\end{tabular}

${ }^{a} n=3$; the RSD of replicate injections was generally below $2.5 \%$.

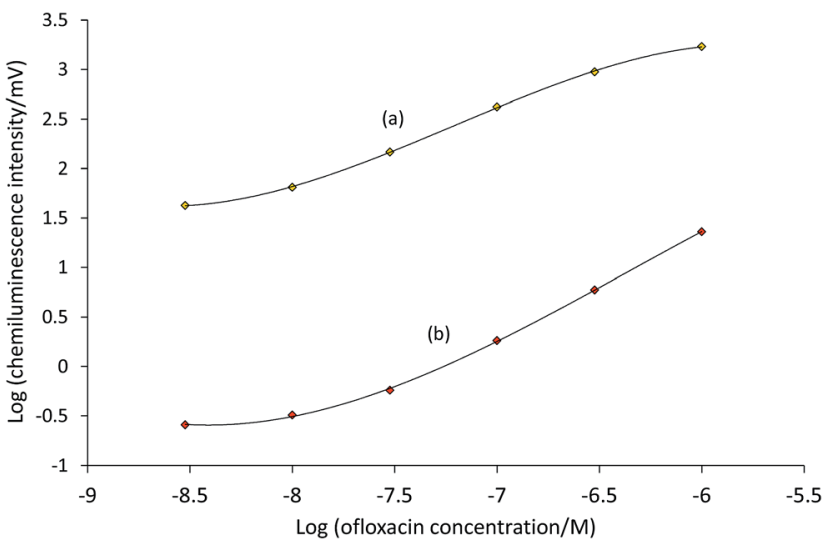

Fig. 5 log-log plot of chemiluminescence intensity versus concentration of ofloxacin for (a) $\left[\mathrm{Ir}(\mathrm{bt})_{2}(\mathrm{BPS})\right]^{-}$, and (b) $\left[\mathrm{Ru}(\mathrm{bpy})_{3}\right]^{2+}$, using flow injection analysis methodology. Reagent: $10 \mu \mathrm{M}$ in $0.05 \mathrm{M} \mathrm{H}_{2} \mathrm{SO}_{4}$. Oxidant: $1 \mathrm{mM}$ cerium(Iv) sulfate in $0.05 \mathrm{M} \mathrm{H}_{2} \mathrm{SO}_{4}$. The lines are third order polynomial fits $\left(R^{2}=0.9999\right.$ and 0.9998$)$, showing the characteristic 'S-shape' of chemiluminescence log-log calibrations over multiple orders of magnitude.

complexes with the acidic aqueous solvent; ${ }^{33}$ (iii) the efficiency that the corresponding excited state is generated; ${ }^{34}$ and (iv) the efficiency of the emission (i.e. photons emitted per excited luminophore molecules). The same or analogous considerations must be made when comparing the different responses of each reagent with the same analyte.

As the emissions corresponding to the solvent (blank) and analyte are both transient and may occur at different rates, the greatest $S / B$ ratio observed in this flow-analytical system was dependent on the solution flow rate, which was optimised for each combination of analyte and reagent.

\section{Theoretical calculations}

Density functional theory (DFT) calculations were employed to examine the electronic structure and nature of the radiative transition of each complex. The molecular orbitals (MOs) of $\left[\mathrm{Ru}(\mathrm{bpy})_{3}\right]^{2+}$ are already well characterised, ${ }^{9,35,36}$ but we start our discussion with this complex for comparison purposes. As shown in Fig. 6a, the HOMO of $\left[\mathrm{Ru}(\mathrm{bpy})_{3}\right]^{2+}$ is metal centred and the LUMO is distributed equally amongst the three bipyridine ligands. The triplet-state spin density (Fig. 7a) shares the same spatial extent as the singlet HOMO and LUMO, for which the
HOMO

(a)
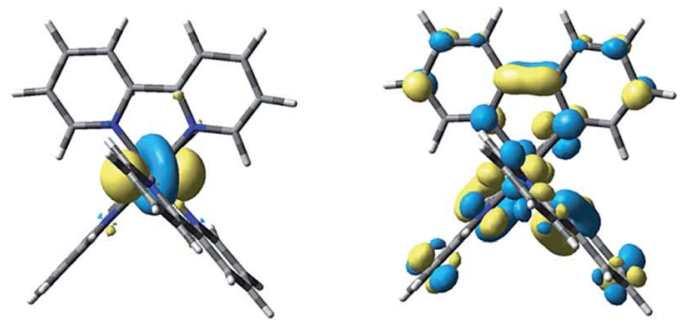

(b)

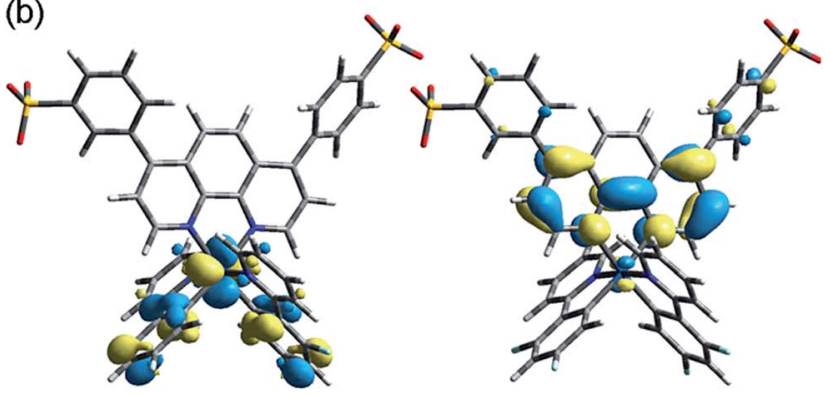

(c)

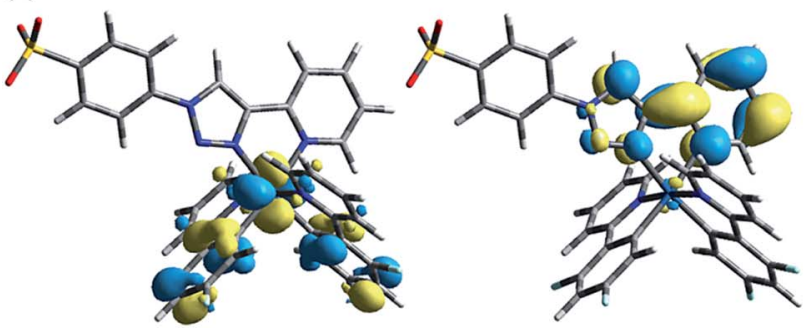

Fig. 6 Ground-state singlet molecular energy surfaces of (a) $\left[\mathrm{Ru}(\mathrm{bpy})_{3}\right]^{2+}$, (b) [lr(df-ppy) $\left.)_{2}(\mathrm{BPS})\right]^{-}$and (c) $\left[\operatorname{lr}(\mathrm{df}-\mathrm{ppy})_{2}(\mathrm{STP})\right]$.

lowest excited state may be described as metal-to-ligand chargetransfer (MLCT). ${ }^{35}$

Analysis of the MOs of [Ir(df-ppy) $\left.)_{2}(\mathrm{BPS})\right]^{-}$(Fig. $6 \mathrm{~b}$ and $7 \mathrm{~b}$ ) is illustrative of the theoretical results for each of the $\left[\operatorname{Ir}\left(\mathrm{C}^{\wedge} \mathrm{N}\right)_{2}(\mathrm{BPS})\right]^{-}$ series (n.b.: frontier MO and triplet spin density surfaces for all complexes are included in Table S1 in ESI $\dagger$ ). The singlet HOMO of $\left[\operatorname{Ir}(\mathrm{df}-\mathrm{ppy})_{2}(\mathrm{BPS})\right]^{-}$is principally composed of a mixture of the iridium $\mathrm{d}$ and the phenyl $\pi$ orbitals, distributed equally across the two $\mathrm{C}^{\wedge} \mathrm{N}$-type df-ppy ligands. The LUMO is localised on the BPS (a)

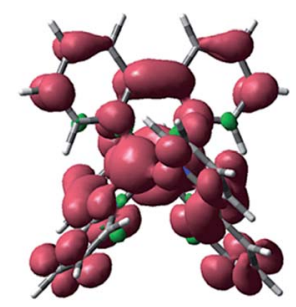

(b)

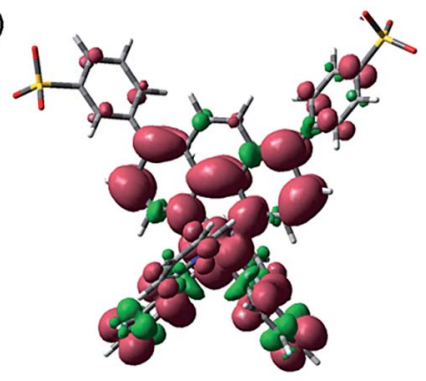

Fig. 7 Triplet spin density surfaces of (a) $\left[\mathrm{Ru}(\mathrm{bpy})_{3}\right]^{2+}$ and (b) $[\operatorname{lr}(\mathrm{df}-$ ppy) $\left.{ }_{2}(\mathrm{BPS})\right]^{-}$. 
ligand, predominantly on the phenanthroline moiety. The triplet spin density surface (Fig. 7b) shares the same spatial extent as the singlet LUMO and $\mathrm{HOMO},{ }^{37}$ which in this case leads to a description of the lowest energy excited state as having metalligand-to-ligand charge-transfer (MLLCT) character.

The results for the novel [Ir(df-ppy $\left.)_{2}(\mathrm{STP})\right]$ complex (Fig. 6c) are analogous to those of the $\left[\operatorname{Ir}\left(\mathrm{C}^{\wedge} \mathrm{N}\right)_{2}(\mathrm{BPS})\right]^{-}$series, where the singlet HOMO is composed of a mixture of the Ir $\mathrm{d}$ and the phenyl $\pi$ orbitals of the df-ppy ligands, and the LUMO is localised on the sulfonate ligand. Mulliken population analysis of fragment contributions to the HOMO and LUMO (Fig. 8) highlighted the similarities of these iridium compounds. In each case, Ir contributes 35-37\% of the HOMO while the phenyl $(\pi)$ ring of the $\mathrm{C}^{\wedge} \mathrm{N}$ ligand contributes $\sim 60 \%$. The LUMO is almost exclusively composed of the sulfonate ligand (94-97\%). The triplet spin density surface of $\left[\operatorname{Ir}(\text { df-ppy })_{2}(\mathrm{STP})\right]$ shares the same spatial extent as the singlet LUMO and HOMO.

For each of the iridium complexes under investigation, there is very little overlap between the singlet-state HOMO and LUMO (i.e. they are largely orthogonal), which indicates that the HOMO and LUMO energies can be independently 'tuned' by appropriate substitution of donor/acceptor groups on the $\mathrm{C}^{\wedge} \mathrm{N}$ or sulfonate ligands, respectively. For example, the HOMO energies for $\left[\operatorname{Ir}(\mathrm{df}-\mathrm{ppy})_{2}(\mathrm{BPS})\right]^{-}$and $\left[\operatorname{Ir}(\mathrm{df}-\mathrm{ppy})_{2}(\mathrm{STP})\right]^{-}$are very similar $(-6.07$ and $-6.11 \mathrm{eV})$, but the LUMO energies are -2.70 and $-2.26 \mathrm{eV}$ (Fig. S1; ESI $\dagger$ ). That is, the common df-ppy ligand
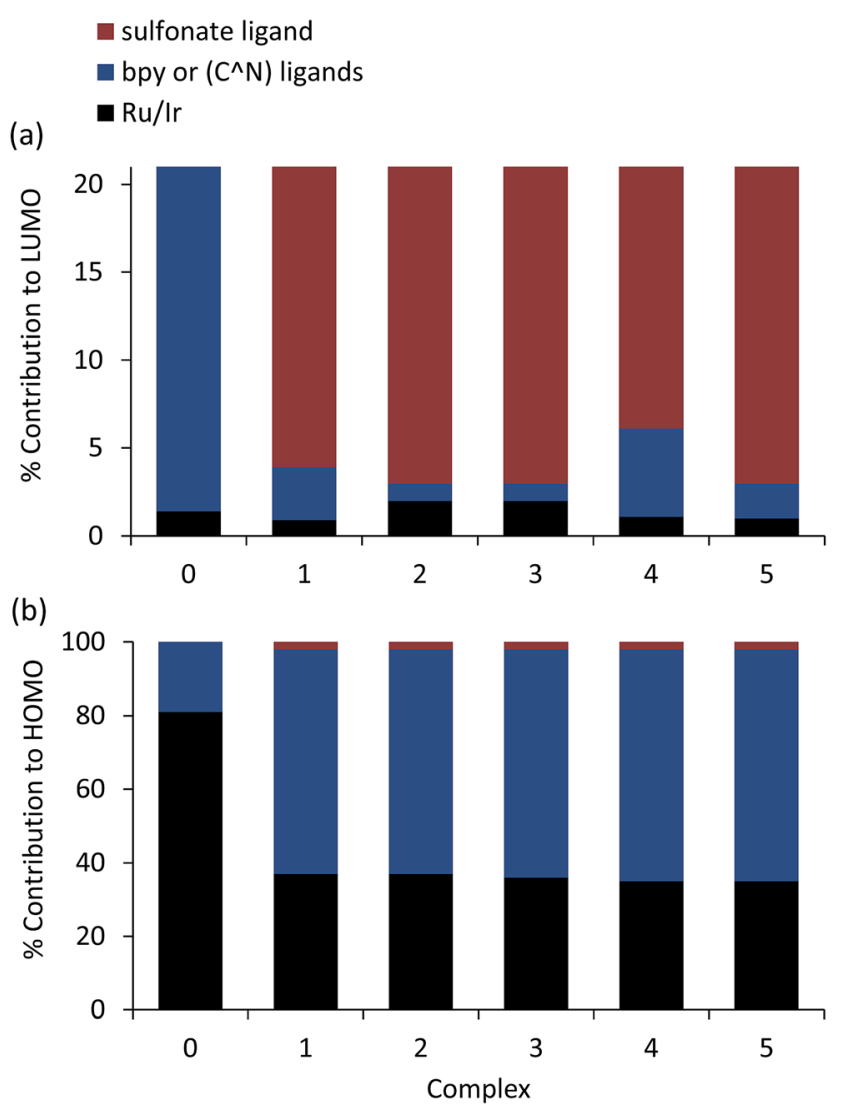

Fig. 8 Contribution to (a) LUMO and (b) HOMO of metal centre and ligands in: (0) $\left[\mathrm{Ru}(\mathrm{bpy})_{3}\right]^{2+}$; (1) $\left[\operatorname{lr}(\mathrm{ppy})_{2}(\mathrm{BPS})\right]^{-} ;$; (2) $\left[\operatorname{lr}(\mathrm{df}-\mathrm{ppy})_{2}(\mathrm{BPS})\right]^{-} ;(3)$ $\left[\operatorname{lr}(\mathrm{bt})_{2}(\mathrm{BPS})\right]^{-}$; (4) $\left[\operatorname{lr}(\mathrm{piq})_{2}(\mathrm{BPS})\right]^{-}$; and (5) [Ir(df-ppy $\left.)_{2}(\mathrm{STP})\right]$. ensures little change to the HOMO properties, but modification of the sulfonate ligand significantly influences the LUMO.

The singlet-triplet transition energy of the complexes can be estimated from the difference between the triplet state highest singly occupied MO (HSOMO) and the singlet HOMO. For example, the B3LYP/def2-TZVP calculated energy difference for $\left[\operatorname{Ir}(\mathrm{bt})_{2}(\mathrm{BPS})\right]^{-}$is $2.32 \mathrm{eV}(534 \mathrm{~nm})$. The experimental measurement is $576 \mathrm{~nm}$, but this is only formally comparable to the theoretical results in the limit of low-temperature measurements (in this work all measurements were recorded at room temperature). Nevertheless, a general trend emerges that the rank order of calculated singlet-triplet energy gaps of the complexes matches that of the experimental results (Fig. S2; ESI $\dagger$ ).

To probe the nature of the luminescence emission bands, TD-DFT calculations of the lowest-energy vertical emissions were carried out (estimated by singlet state TD-DFT calculations at the triplet-state optimised geometries; Table S2 $\dagger$ ). As discussed above, for the iridium compounds (Fig. 6 and 8), a HOMO-LUMO transition would be attributed to a mixture of MLCT and LLCT (HOMO is Ir d orbital and $\pi$ orbital of the $\mathrm{C}^{\wedge} \mathrm{N}$ ligand, LUMO is on the sulfonate ligand). However, the emission spectrum arises from a range of electronic transitions, and moreover, the HOMO-LUMO transition is not necessarily the dominant transition.

TD-DFT results indicate that the complexes that contain the df-ppy ligand exhibit emission bands with significant ligandcentred (LC) character. For $\left[\operatorname{Ir}(\mathrm{df}-\mathrm{ppy})_{2}(\mathrm{BPS})\right]^{-}$, the LC transition occurs within the BPS ligand (HOMO-1 to LUMO), while for $\left[\operatorname{Ir}(\mathrm{df}-\mathrm{ppy})_{2}(\mathrm{STP})\right]^{-}$, the LC transition occurs within the df-ppy ligand (HOMO to LUMO+1). Similarly, both the $\left[\operatorname{Ir}(\mathrm{bt})_{2}(\mathrm{BPS})\right]^{-}$ and $\left[\operatorname{Ir}(\mathrm{piq})_{2}(\mathrm{BPS})\right]^{-}$complexes are predicted to exhibit some LC character. The $\left[\operatorname{Ir}(\mathrm{ppy})_{2}(\mathrm{BPS})\right]^{-}$and $\left[\operatorname{Ir}(\mathrm{ppy})_{2}(\mathrm{STP})\right]^{-}$complexes are not expected to show LC character, but are dominated by MLCT and LLCT transitions.

In general, emission bands from charge-transfer (CT) states are broad and featureless, while ligand-centred (LC) states typically give emissions with vibronic structure. ${ }^{32}$ The presence of vibronic structure in the emission spectra of [Ir(df-ppy $\left.)_{2}(\mathrm{BPS})\right]^{-}$ and $\left[\operatorname{Ir}(\mathrm{df}-\mathrm{ppy})_{2}(\mathrm{STP})\right]^{-}$(Fig. 4) is indicative of contributions from ligand-centred (LC) transitions, ${ }^{38,39}$ and is consistent with the theoretical results. The $\left[\operatorname{Ir}(\mathrm{bt})_{2}(\mathrm{BPS})\right]^{-}\left(\right.$Fig. 4) and $\left[\operatorname{Ir}(\text { piq })_{2}(\mathrm{BPS})\right]^{-}$ (not shown) complexes also exhibit minor shoulder bands that are attributed to LC transitions. The emission bands of $\left[\operatorname{Ir}(\mathrm{ppy})_{2}(\mathrm{BPS})\right]^{-}$and $\left[\operatorname{Ir}(\mathrm{ppy})_{2}(\mathrm{STP})\right]^{-}$(not shown) are broad and featureless, consistent with MLCT and LLCT (MLLCT) character.

\section{Mechanism considerations}

The mechanism of chemiluminescent reactions of ruthenium(II) and related metal complexes with tertiary amines is well established (Fig. 9a). ${ }^{\mathbf{3 0 , 3 1 , 4 0}}$ Oxidation of the tertiary amine by cerium(Iv) or by the oxidised metal complex $\left(\mathrm{M}^{+}\right)$initially forms an aminium radical cation that decomposes to form a highly reductive alkyl radical species. The reaction of this intermediate with the oxidised metal complex can generate the electronically excited emissive species. 


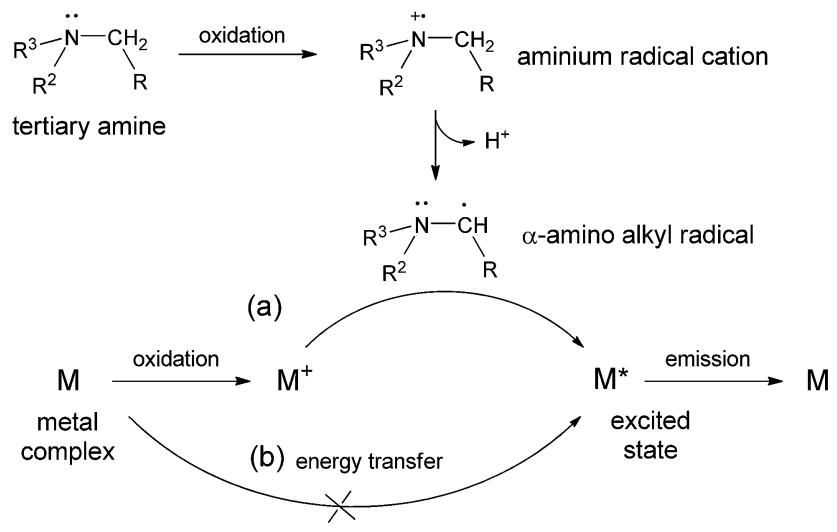

Fig. 9 (a) Generalised mechanism of the chemiluminescence reactions of transition metal complexes with tertiary amines, ${ }^{30,31,40}$ and (b) an alternative light producing pathway involving energy transfer from an excited intermediate derived from the tertiary amine.

We also observed a weak emission of light from the reaction of cerium(Iv) with ofloxacin, in the absence of the metal complex, indicating that another electronically excited species (derived from the tertiary amine compound) can be generated in this reaction. In the presence of the metal complex, the contribution of the direct emission from the alternative excited state species to the overall chemiluminescence would not be significant. However, it is possible that the alternative excited species is capable of transferring energy to the more efficient metal complex luminophore (Fig. 9b), and this alternative light producing pathway could make a significant contribution to the overall emission.

To test the contribution of this alternative light-producing pathway, we replaced the metal complexes with two efficient luminophores, rhodamine $\mathrm{B}$ and quinine. These compounds have commonly been used to sensitise the weak chemiluminescence oxidation of various organic compounds with strong inorganic oxidants such as cerium(Iv), bromate and permanganate. ${ }^{\mathbf{4 1 - 4 5}}$ However, in this case, no significant emission from either luminophore was observed, indicating that the postulated energy transfer pathway (Fig. 9b) does not make a significant contribution to the chemiluminescence reaction of metal complexes.

The increased sensitivity of certain iridium complex reagents compared to $\left[\mathrm{Ru}(\mathrm{bpy})_{3}\right]^{2+}$ was therefore largely attributed to a combination of their greater reactivity with the analytes after oxidation, in addition to superior excitation and/or luminescence efficiencies. Moreover, the observed analyte dependence of these effects highlights the relative importance of the reactivity of the respective oxidised complex towards the analyte to generate the radical intermediates, and towards the $\alpha$-amino alkyl radical as the source of chemi-excitation.

\section{Experimental}

\section{Instrumentation}

Flow injection analysis with chemiluminescence detection. For the preliminary comparison of $\left[\operatorname{Ir}\left(\mathrm{C}^{\wedge} \mathrm{N}\right)_{2}(\mathrm{BPS})\right]^{-}$complexes against $\left[\mathrm{Ru}(\mathrm{bpy})_{3}\right]^{2+}$ (Table 2), the manifold was constructed and experiments performed as previously described. ${ }^{17}$ For the subsequent comparisons (Table 3), the manifold was identical, except that a GloCel detector with dual-inlet serpentine flowcell $^{28}$ was used. In this case, chemiluminescence intensities were established by injecting $70 \mu \mathrm{L}$ of each metal complex reagent into the chemical oxidant stream (1 $\mathrm{mM}$ cerium(Iv) sulfate in $0.05 \mathrm{M} \mathrm{H}_{2} \mathrm{SO}_{4}$ ), which then merged with the analyte or deionised water 'blank' solution in the dual-inlet flow cell. For each reagent/analyte combination, flow rates were optimised between 1 and $3.5 \mathrm{~mL} \min ^{-1}$ per line, to achieve the greatest signal-to-blank ratio.

Photoluminescence. A Varian Cary Eclipse fluorescence spectrophotometer was used to collect photoluminescence spectra, which were corrected for the wavelength dependence of the detector response and monochromator transmission as previously described. ${ }^{29}$

Electrochemistry. Oxidation potentials were measured using an Autolab PGSTAT12 potentiostat with three-electrode configuration: working electrode: glassy carbon; counter: Pt wire; reference: $\mathrm{Ag} / \mathrm{AgCl}$.

\section{Chemicals and reagents}

Bis(2-phenylbenzothiazole)(bathophenanthrolinedisulfonate)iridium(III); bis(2-(difluorophenyl)pyridine)(bathophenanthrolinedisulfonate)iridium(III); and bis(1-phenylisoquinoline)(bathophenanthrolinedisulfonate)iridium(III) were provided by SunaTech (Suzhou, P. R. China). In each of these complexes, the BPS ligand was the para-, meta $^{\prime}$-isomer. ${ }^{23}$

Synthesis of the thiol ligand (7; Fig. 3a). 4-Azidobenzene thiol (300 mg, $1.98 \mathrm{mmol}$ ) and 2-ethynyl pyridine (200 $\mu \mathrm{L}, 1.98 \mathrm{mmol})$ were suspended in water $\left(3 \mathrm{~mL}\right.$ ) followed by the addition of $\mathrm{CuSO}_{4}$ (10 mol\%, $25 \mathrm{mg} \mathrm{mL}^{-1}$ in $\mathrm{H}_{2} \mathrm{O}$ ) and ascorbic acid (20 mol\%, $20 \mathrm{mg}$ $\mathrm{mL}^{-1}$ in $\mathrm{H}_{2} \mathrm{O}$ ). The reaction mixture was heated to $100{ }^{\circ} \mathrm{C}$ and stirred for 30 min using microwave irradiation. The solution was diluted with water $(5 \mathrm{~mL})$ and extracted into $\mathrm{CH}_{2} \mathrm{Cl}_{2}(3 \times 15 \mathrm{~mL})$. The resulting organic layer was dried over $\mathrm{MgSO}_{4}$ and the solvent removed in vacuo to give the crude material. The crude brown crystals were recrystallised from $\mathrm{CHCl}_{3}$ : PET spirits $(1: 10 \mathrm{v} / \mathrm{v})$ and the product collected in a Hirsch funnel to give a light brown powder (268 mg, 53\%). Analysis of the solid material by ${ }^{1} \mathrm{H}$ NMR spectroscopy showed the desired compound in $>95 \%$ purity. ${ }^{1} \mathrm{H}$ NMR $\left(d_{6}\right.$-DMSO, $\left.270 \mathrm{MHz}\right): \delta 9.34(1 \mathrm{H}, \mathrm{s}, \mathrm{Ar}-\mathrm{H}), 8.67-8.63(1 \mathrm{H}, \mathrm{m}$, Ar-H), 8.14-8.06 (3H, m, Ar-H), 7.95 (1H, td, $J=8.1,2.7 \mathrm{~Hz}, \mathrm{Ar}-\mathrm{H})$, $7.81(2 \mathrm{H}, \mathrm{d}, J=8.1 \mathrm{~Hz}, \mathrm{Ar}-\mathrm{H}), 7.43-7.37(1 \mathrm{H}, \mathrm{m}, \mathrm{Ar}-\mathrm{H}), \mathrm{SH}$ not observed; ${ }^{13} \mathrm{C}$ NMR $\left(d_{6}\right.$-DMSO, $\left.67.5 \mathrm{MHz}\right): \delta 150.3,149.9,148.8$, 137.9, 136.6, 136.4, 129.1, 123.9, 121.9, 121.8, 120.4 .

Synthesis of thiol complex (9; Fig. 3b). This complex was prepared by modification of previously reported procedures. ${ }^{9,46}$ To a solution of 7 (25 mg, $0.098 \mathrm{mmol})$ in dichloromethane $(10 \mathrm{~mL})$, $\left[\left\{(\text { df-ppy })_{2} \operatorname{Ir}\right\}_{2}(\mu-\mathrm{Cl})_{2}\right] \quad(59 \mathrm{mg}, 0.049 \mathrm{mmol})$ was added. The suspension was refluxed under nitrogen for $24 \mathrm{~h}$, during which time dissolution of the solid occurred. The yellow solution was evaporated to dryness then dissolved in acetone $(3 \mathrm{~mL})$ and saturated $\mathrm{KPF}_{6}$ solution was added. The resulting precipitate was filtered, and washed with water and then ether. The solid was dried in vacuo at $50{ }^{\circ} \mathrm{C}$ to yield the product as a yellow powder (yield: 
83\%). ${ }^{1} \mathrm{H}$ NMR $\left(d-\mathrm{CDCl}_{3}, 270 \mathrm{MHz}\right): \delta 6.62(2 \mathrm{H}, \mathrm{m}, \mathrm{Ar}-\mathrm{H}), 6.90-7.05$ (2H, m, Ar-H), 7.22-7.29 (2H, m, Ar-H), 7.64 (1H, m, Ar-H), 7.767.85 (6H, m, Ar-H), 7.94-8.05 (3H, m, Ar-H), 8.26-8.39 (4H, m, ArH), 10.12 (1H, s, Ar-H).

Preparation of $\left[\operatorname{Ir}(\mathbf{d f}-\mathbf{p p y})_{2}(\mathbf{S T P})\right](5 ;$ Fig. 1b). The corresponding thiol complex (9) was dissolved in a minimum amount of acetone. An aqueous solution of Oxone (potassium peroxymonosulfate; 1.1 equiv.) was added. The yellow solution was filtered and then heated to $35^{\circ} \mathrm{C}$ for $1 \mathrm{~h}$ to remove the acetone. The reagent was then directly prepared, without further isolation of the product, by appropriate dilution with an aqueous sulfuric acid solution. The conversion of the thiol (9) to the sulfonate (5) was confirmed by high resolution mass spectrometry (calculated for $\mathrm{C}_{35} \mathrm{H}_{21} \mathrm{~F}_{4} \mathrm{IrN}_{6}$ $\mathrm{O}_{3} \mathrm{~S}$ : 875.10340; found: 875.10340), where the characteristic isotope pattern of the product was observed. The starting material (9) was not detected (relative peak intensity $<0.2 \%$, attributable to background noise).

\section{Computational methods}

DFT calculations were carried out within the Gaussian 09 suite of programs. ${ }^{47}$ Ground and triplet state geometries were optimised in the absence of solvent with the mPW1PW91 (ref. 47 and 48) functional in conjunction with the def2-SVP basis set and associated core potential. ${ }^{49}$ The mPW1PW91 functional has previously been demonstrated to yield reliable results for such systems. ${ }^{36,50}$ Stationary points were characterised as minima by calculating the Hessian matrix analytically at the same level of theory. All structures are minima with no imaginary frequencies. Due to difficulties with the $D_{3}$ symmetry triplet state of $\left[\mathrm{Ru}(\mathrm{bpy})_{3}\right]^{2+}$, a previously reported $^{51}$ B3PW91/LANL2DZ calculated structure was used. Single-point energy calculations were carried out with the B3LYP functional $^{52-54}$ and def2-TZVP basis set and core potential. ${ }^{49}$ TDDFT calculations of emission bands were calculated at the B3LYP/ def2-SVP level of theory as singlet states at the triplet-state optimised geometry, which represents a vertical triplet-singlet transition; 20 singlet and triplet states were calculated with TD-DFT. The polarisable continuum model (PCM) ${ }^{55}$ self-consistent reaction field (SCRF) was used to model solvent effects at the gas-phase optimised geometries with a solvent of acetonitrile or water, for consistency with the experimental system. The water and acetonitrile solvent results were almost identical; hence only water solvent results are presented. An SCF convergence criterion of $10^{-8}$ a.u. was employed throughout. Molecular orbital analysis was carried out with the AOMix program. ${ }^{56}$

\section{Conclusions}

Chemiluminescence detection with iridium(III) complexes containing an ancillary BPS ligand provided a wide range of emission colours (green to red) from respective excited states. All complexes exhibited MLLCT emission bands, but [Ir(df-ppy) $\left.)_{2}(\mathrm{BPS})\right]^{-}$(and to a much lesser extent, $\left[\operatorname{Ir}(\mathrm{bt})_{2}(\mathrm{BPS})\right]^{-}$and $\left.\left[\operatorname{Ir}(\mathrm{piq})_{2}(\mathrm{BPS})\right]^{-}\right)$also demonstrated LC emission character. Unlike previous comparisons of ECL, greater chemiluminescence responses were often obtained using the green-light emitting [Ir(df-ppy) $\left.)_{2}(\mathrm{BPS})\right]^{-}$and yellow-light emitting $\left[\operatorname{Ir}(\mathrm{bt})_{2}(\mathrm{BPS})\right]^{-}$complexes than $\left[\mathrm{Ru}(\mathrm{bpy})_{3}\right]^{2+}$.
Most notably, the chemiluminescence response of each analyte with $\left[\operatorname{Ir}(\mathrm{bt})_{2}(\mathrm{BPS})\right]^{-}$(and cerium(Iv)) was over an order of magnitude greater than those of $\left[\mathrm{Ru}(\mathrm{bpy})_{3}\right]^{2+}$ in acidic aqueous solution. However, the blank responses (from the competing reaction of the oxidised complex with the solvent) were also greater, limiting the translation of the enhanced sensitivity to superior limits of detection. An iridium(III) complex containing an ancillary STP ligand exhibited a blue emission, again attributable to MLLCT and LC transitions, but the chemiluminescence intensities of this complex were poor compared to $\left[\mathrm{Ru}(\mathrm{bpy})_{3}\right]^{2+}$ and the other iridium complexes. Nevertheless, these findings have created new directions for the development of water-soluble iridium(III) complexes as chemiluminescence reagents.

\section{Acknowledgements}

This research was funded by the Australian Research Council (FT100100646). We thank the Victorian Partnership for Advanced Computing (VPAC), the National Computational Infrastructure National Facility (NCI-NF) and La Trobe University for computing resources.

\section{Notes and references}

1 A. Kapturkiewicz and G. Angulo, Dalton Trans., 2003, 39073913.

2 M. M. Richter, Chem. Rev., 2004, 104, 3003-3036.

3 W. Miao, Chem. Rev., 2008, 108, 2506-2553.

4 S. Zanarini, E. Rampazzo, S. Bonacchi, R. Juris, M. Marcaccio, M. Montalti, F. Paolucci and L. Prodi, J. Am. Chem. Soc., 2009, 131, 14208-14209.

5 R. V. Kiran, C. F. Hogan, B. D. James and D. J. D. Wilson, Eur. J. Inorg. Chem., 2011, 4816-4825.

6 S. Zanarini, M. Felici, G. Valenti, M. Marcaccio, L. Prodi, S. Bonacchi, P. Contreras-Carballada, R. M. Williams, M. C. Feiters, R. J. M. Nolte, L. De Cola and F. Paolucci, Chem.-Eur. J., 2011, 17, 4640-4647.

7 K. N. Swanick, S. Ladouceur, E. Zysman-Colman and Z. Ding, Chem. Commun., 2012, 48, 3179-3181.

8 K. N. Swanick, S. Ladouceur, E. Zysman-Colman and Z. Ding, Angew. Chem., Int. Ed., 2012, 51, 11079-11082.

9 G. J. Barbante, E. H. Doeven, E. Kerr, T. U. Connell, P. S. Donnelly, J. M. White, T. Lópes, S. Laird, C. F. Hogan, D. J. D. Wilson, P. J. Barnard and P. S. Francis, Chem.-Eur. J., 2014, 20, 3322-3332.

10 D. Bruce and M. M. Richter, Anal. Chem., 2002, 74, 13401342.

11 B. D. Muegge and M. M. Richter, Anal. Chem., 2004, 76, 73-77. 12 E. H. Doeven, E. M. Zammit, G. J. Barbante, C. F. Hogan, N. W. Barnett and P. S. Francis, Angew. Chem., Int. Ed., 2012, 51, 4354-4357.

13 E. H. Doeven, E. M. Zammit, G. J. Barbante, P. S. Francis, N. W. Barnett and C. F. Hogan, Chem. Sci., 2013, 4, 977-982.

14 E. H. Doeven, G. J. Barbante, E. Kerr, C. F. Hogan, J. A. Endler and P. S. Francis, Anal. Chem., 2014, 86, 2727-2732.

15 R. V. Kiran, E. M. Zammit, C. F. Hogan, B. D. James, N. W. Barnett and P. S. Francis, Analyst, 2009, 134, 1297-1298. 
16 J. M. Terry, E. M. Zammit, T. Slezak, N. W. Barnett, D. C. Olson, D. K. Wolcott, D. L. Edwards and P. S. Francis, Analyst, 2011, 136, 913-919.

17 E. M. Zammit, N. W. Barnett, L. C. Henderson, G. A. Dyson, M. Zhou and P. S. Francis, Analyst, 2011, 136, 3069-3072.

18 F. Wu, B. Tong and Q. Zhang, Anal. Sci., 2011, 27, 529-533.

19 F. Wu, B. Tong, X. Wei and L. Chen, Luminescence, 2012, 27, 519-523.

20 Y. P. Dong, L. Huang, B. H. Tong, M. J. Shi, W. B. Zhang and Q. F. Zhang, Luminescence, 2012, 27, 262-267.

21 Y. P. Dong, M. J. Shi, B. H. Tong and Q. F. Zhang, Luminescence, 2012, 27, 414-418.

22 C. Liu, L. Yu, Y. Liu, L. Fang and M. Zhou, Magn. Reson. Chem., 2011, 49, 816-823.

23 L. Yu, Z. Huang, Y. Liu and M. Zhou, J. Organomet. Chem., 2012, 718, 14-21.

24 J. Jia, H. Fei and M. Zhou, Electrophoresis, 2012, 33, 1397-1401. 25 S. A. De Pascali, D. Migoni, P. Papadia, A. Muscella, S. Marsigliante, A. Ciccarese and F. P. Fanizzi, Dalton Trans., 2006, 5077-5087.

26 G. P. McDermott, E. M. Zammit, E. K. Bowen, M. M. Cooke, J. L. Adcock, X. A. Conlan, F. M. Pfeffer, N. W. Barnett, G. A. Dyson and P. S. Francis, Anal. Chim. Acta, 2009, 634, 222-227.

27 L. Della Ciana, S. Zanarini, R. Perciaccante, E. Marzocchi and G. Valenti, J. Phys. Chem. C, 2010, 114, 3653-3658.

28 J. M. Terry, J. L. Adcock, D. C. Olson, D. K. Wolcott, C. Schwanger, L. A. Hill, N. W. Barnett and P. S. Francis, Anal. Chem., 2008, 80, 9817-9821.

29 P. S. Francis, J. L. Adcock and N. W. Barnett, Spectrochim. Acta, Part A, 2006, 65, 708-710.

30 W. Miao, J.-P. Choi and A. J. Bard, J. Am. Chem. Soc., 2002, 124, 14478-14485.

31 C. M. Hindson, G. R. Hanson, P. S. Francis, J. L. Adcock and N. W. Barnett, Chem.-Eur. J., 2011, 17, 8018-8022.

32 F. Neve, M. La Deda, A. Crispini, A. Bellusci, F. Puntoriero and S. Campagna, Organometallics, 2004, 23, 5856-5863.

33 R. D. Gerardi, N. W. Barnett and P. Jones, Anal. Chim. Acta, 1999, 388, 1-10.

34 P. S. Francis and J. L. Adcock, Chromatogr. Sci. Ser., 2012, 104, 221-250.

35 S. Campagna, F. Puntoriero, F. Nastasi, G. Bergamini and V. Balzani, Top. Curr. Chem., 2007, 280, 117-214.

36 G. J. Barbante, C. F. Hogan, D. J. D. Wilson, N. A. Lewcenko, F. M. Pfeffer, N. W. Barnett and P. S. Francis, Analyst, 2011, 136, 1329-1338.

37 A. B. Tamayo, S. Garon, T. Sajoto, P. I. Djurovich, I. M. Tsyba, R. Bau and M. E. Thompson, Inorg. Chem., 2005, 44, 87238732 .

38 Q. Zhao, M. Yu, L. Shi, S. Liu, C. Li, M. Shi, Z. Zhou, C. Huang and F. Li, Organometallics, 2010, 29, 1085-1091.

39 E. Orselli, R. Q. Albuquerque, P. M. Fransen, R. Fröhlich, H. M. Janssen and L. De Cola, J. Mater. Chem., 2008, 18, 4579-4590.
40 Y. Yuan, S. Han, L. Hu, S. Parveen and G. Xu, Electrochim. Acta, 2012, 82, 484-492.

41 J. S. Lancaster, P. J. Worsfold and A. Lynes, Analyst, 1989, 144, 1659-1661.

42 F. A. Aly, N. A. Alarfaj and A. A. Alwarthan, Anal. Chim. Acta, 1998, 358, 255-262.

43 B. Li, Z. Zhang, M. Liu and C. Xu, Anal. Bioanal. Chem., 2003, 377, 1212-1216.

44 P. S. Francis, A. J. Brown, S. A. Bellomarino, A. M. Taylor, T. Slezak and N. W. Barnett, Luminescence, 2009, 24, 90-95.

45 J. L. Adcock, P. S. Francis and N. W. Barnett, J. Fluoresc., 2009, 19, 867-874.

46 M. Mydlak, C. Bizzarri, D. Hartmann, W. Sarfert, G. Schmid and L. De Cola, Adv. Funct. Mater., 2010, 20, 1812-1820.

47 M. J. Frisch, G. W. Trucks, H. B. Schlegel, G. E. Scuseria, M. A. Robb, J. R. Cheeseman, G. Scalmani, V. Barone, B. Mennucci, G. A. Petersson, H. Nakatsuji, M. Caricato, X. Li, H. P. Hratchian, A. F. Izmaylov, J. Bloino, G. Zheng, J. L. Sonnenberg, M. Hada, M. Ehara, K. Toyota, R. Fukuda, J. Hasegawa, M. Ishida, T. Nakajima, Y. Honda, O. Kitao, H. Nakai, T. Vreven, J. J. A. Montgomery, J. E. Peralta, F. Ogliaro, M. Bearpark, J. J. Heyd, E. Brothers, K. N. Kudin, V. N. Staroverov, R. Kobayashi, J. Normand, K. Raghavachari, A. Rendell, J. C. Burant, S. S. Iyengar, J. Tomasi, M. Cossi, N. Rega, J. M. Millam, M. Klene, J. E. Knox, J. B. Cross, V. Bakken, C. Adamo, J. Jaramillo, R. Gomperts, R. E. Stratmann, O. Yazyev, A. J. Austin, R. Cammi, C. Pomelli, J. W. Ochterski, R. L. Martin, K. Morokuma, V. G. Zakrzewski, G. A. Voth, P. Salvador, J. J. Dannenberg, S. Dapprich, A. D. Daniels, Ö. Farkas, J. B. Foresman, J. V. Ortiz, J. Cioslowski and D. J. Fox, Gaussian 09, Revision A.1, Gaussian, Inc., Wallingford CT, 2009.

48 J. P. Perdew, in Electronic Structure of Solids '91, ed. P. Ziesche and H. Eschrig, Akademie Verlag, Berlin, 1991, pp. 11-20.

49 F. Weigend and R. Ahlrichs, Phys. Chem. Chem. Phys., 2005, 7, 3297-3305.

50 J. Lin, K. Wu and M. Zhang, J. Comput. Chem., 2009, 30, 2056-2063.

51 K. Nozaki, K. Takamori, Y. Nakatsugawa and T. Ohno, Inorg. Chem., 2006, 45, 6161-6178.

52 A. D. Becke, Phys. Rev. A: At., Mol., Opt. Phys., 1988, 38, 30983100 .

53 A. D. Becke, J. Chem. Phys., 1993, 98, 5648-5652.

54 C. Lee, W. Yang and R. G. Parr, Phys. Rev. B: Condens. Matter, 1988, 37, 785-789.

55 J. Tomasi, B. Mennucci and R. Cammi, Chem. Rev., 2005, 105, 2999-3093.

56 S. I. Gorelsky, AOMix: Program for Molecular Orbital Analysis, Version 6.46, University of Ottawa, 2010, http://www.sgchem.net/. 